\title{
Socio- Personal, Economic and Psychological Status of Buffalo Owners in Murrah Breeding Tract of Haryana
}

\author{
Rekha Yadav ${ }^{\text {** }}$, Hema Tripathi ${ }^{2}$, Parveen Kumar $^{3}$ and Nukala Ramesh ${ }^{4}$ \\ ${ }^{1}$ Department of Animal Husbandry \& Dairying, Government of Haryana, India \\ ${ }^{2}$ TOTE, ICAR-CIRB Hisar \\ ${ }^{3}$ Division of Veterinary Microbiology, LUVAS, Hisar \\ ${ }^{4}$ Division of Extension Education, ICAR-IVRI, Izatnagar, Bareilly (U.P.), India \\ *Corresponding author
}

\begin{abstract}
A B S T R A C T
Keywords

Buffalo owners, Socio- personal, Economic and psychological status, Murrah breeding tract

Article Info

Accepted:

22 July 2019

Available Online:

10 August 2019

Present study was conducted with objective to explore the socio- personal, economic and psychological characteristics and information seeking behaviour of buffalo owners in Hisar and Jind district i.e. part of Murrah breeding tract of Haryana. Data was collected by interviewing 240 buffalo owners personally. Study revealed that majority of respondents were found in age group of 37-57 years, came from nuclear and small size family, medium family education status, small herd size, high risk orientation and medium economic motivation. Majority had less than 2 ha of land, agriculture as main occupation and belonged to low annual gross income category by earning $\leq$ Rs. 400000 per annum. They were utilizing informal sources for getting information related to animal husbandry at low level, medium level of formal and mass media sources.

\section{Introduction}

India's livestock sector is one of the largest in the world with a holding of 11.6 per cent of world livestock population (512.06 million) comprising of buffaloes $(57.83 \%$ ) (Livestock census, 2012). Contribution of agriculture in GDP of country is 17.4 per cent (India Economic survey, 2015-16), in which animal husbandry and dairy constitute 33 per cent. India is the largest producer of milk i.e. 165.4

million tonnes (NDDB, 2017), with 49 per cent share of buffalo (DAHDF, 2016-17). Livestock population has been decreased by 3.33 per cent while, the population of buffalo has increased by 3.19 per cent (Livestock census, 2012). Livestock contributed $16 \%$ to the income of small farm households as against an average of $14 \%$ for all rural households (Livestock census, 2012). Livestock provides livelihood to two-third of the rural community. It also provides
\end{abstract}


employment to about $8.8 \%$ of the population in India. For further improve the contribution of this sector in livelihood security there is need that farmers should have access to technology, training, resources and veterinary extension services rendered by public sector or private. So, there is indispensable need of the service providers to know about the socioeconomic status of the livestock farmers to provide aforesaid services need based and efficiently. Keeping in view, the present study was designed with the objective of studying the socio-personal, economic and psychological profile of the buffalo owners.

\section{Materials and Methods}

The present study was carried out following ex-post facto and exploratory research design in Murrah breeding tract of Haryana comprising seven districts. Amongst these, 2 districts; Hisar and Jind were selected purposively for the study because of familiarity of the researcher with the local language, customs and culture that helped in building up rapport with the respondents. From each of the selected districts, 120 buffalo owners were selected randomly, thus 240 respondents were selected and data were collected by personal interview and observation and results were expressed in frequency and per cent.

\section{Results and Discussion}

\section{Socio-personal profile of the buffalo owners}

This includes the age, caste, type of house, family type, family size, family education status, family main occupation, herd size and herd structure.

Age

Table 1 reveals that nearly forty six percent of respondents were in middle age group (3757 years), followed by young (32.9\%) and 20.8 per cent fell under 57-76 years of age group. The mean age was 44 years. Earlier studies conducted by Pavan et al., (2016) in Karnatka and Sabapara et al., (2016) in southern Gujarat on dairy animal keepers also find that more number of respondents fell under middle age category.

\section{Caste}

Table further shows that overall majority of respondents $(75.8 \%)$ belonged to General category, followed by Schedule caste $(12.9 \%)$ and rest 11.3 per cent belonged to other backward class category. This indicates that buffalo rearing occupation is not restricted to any one caste or category in Haryana.

\section{Type of house}

Majority of respondents $(91.7 \%)$ were having Pucca house followed by mixed (7.1\%), Kuchha (1.3\%) and no one was having hut in studied area. It indicate that buffalo farmers in Haryana are quite progressive and had Pucca house for their living.

\section{Family structure}

Family structure included family size and family type.

\section{Family type}

Majority $(73.7 \%)$ of respondents came from nuclear family system and rest 26.3 per cent belonged to joint family (Table 4.2). Sarita et al., (2016) also report that majority (73.3\%) of dairy farmers in Hisar district of Haryana has nuclear family system.

\section{Family size}

Table indicates that majority of respondents 
(73.3\%) had small size family i.e. up to seven (7) members followed by respondents (22.1\%) having medium size family comprising 8-11 members. Only few per cent of respondents (4.6\%) also had large size family with more than 12 members. Jyoti (2015) and Pavan et al., (2016) while studying on dairy farmers in Uttar Pradesh and Karnataka, find that majority of respondents have medium size family with 46 members. However, Devaki et al., (2015), Balaraju (2016) and Rekha et al., (2017) report that majority of dairy farmers in Tamilnadu, Karnataka and Haryana state have small family size.

\section{Family education status}

Table 1 points out that majority of respondents $(61.7 \%)$ fell under medium followed by high (34.2\%) and low (4.2\%) family education status categories with mean schooling of $4.83 \pm 1.29$ years. Results are in consonance with Balaraju (2016) who also find that more number of respondents $(43 \%)$ belonged to medium family education status. However Rekha et al., (2017) reveal that majority of women dairy farmers $(57.78 \%)$ in Rewari district of Haryana belonged to low family education status. The differences may be due to the gender as in present study cent per cent respondents were male.

\section{Family land holding}

The mean size of land holding was 1.88 ha per family. More number of respondents (29.6\%) belonged to large farmers category followed by small (28.7\%) and marginal (27.1\%). Rest 14.6 per cent respondents were landless. Rachna et al., (2017) while studying on dairy farmers reveals that family land holding varies between 1 to 6 acres in Haryana. The results of study indicate that buffalo owning farmers of Haryana had large size of land holding as majority owned more than one hectare of land and this is quite high as national average land holding size is 0.12 ha (World bank, 2015).

\section{Family occupation}

Agriculture was found to be main occupation revealed by majority of respondents $(60.0 \%)$ followed by animal husbandry (16.2\%), government service (11.2\%), self-employed (5.8\%) and equal per cent of respondents were engaged in private service and labour (3.3\% each). It clearly revealed that agriculture is still main livelihood source in studied area. The reason being that more than half of the country's population depend on agriculture for employment and state of Haryana is no exception to it. Livestock sector act as a source for supplying additional family income, milk, meat, manure, fuel and drought power. The present study are in line with many studies conducted recently by Prakash et al., (2014), Adesh et al., (2014), Rekha (2015) and Balaraju (2016) wherein majority of respondents have agriculture as their main occupation in various state of India including Haryana.

\section{Herd size}

Table 1 indicates that majority of sampled household $(71.7 \%)$ had small size of livestock holding comprising of $\leq 5.0$ cattle equivalent score followed by medium (18.8\%) and large livestock holding $(9.5 \%)$ with respective cattle equivalents score of 5.1-10.0 and $\geq 10$ animal heads. An average size of livestock holding was 4.9 as per cattle equivalent score. Earlier authors Sabapara et al., (2016), Rekha et al., (2017) also reported small herd size being maintained by majority of dairy farmers in southern Gujarat and Haryana respectively.

\section{Herd composition}

Perusal of the Table 1 reveals that majority of 
respondents $(64.2 \%)$ were rearing exclusively buffalo followed by combination of buffalo + cattle $(34.5 \%)$ and buffalo + small ruminant $(1.3 \%)$. People of Haryana generally rear the good quality animals for milk because it is one of the major dietary components of routine life and studied area also being the breeding tract of Murrah breed. This may be one of the reasons that majority were rearing buffalo only. The distribution was common in both the selected locales under study.

\section{Information seeking behaviour}

Information seeking behaviour was measured by dividing the sources of information in three categories i.e. formal, informal and mass media. For each source, data were collected on three point continuum scale i.e. Always, Sometime and Never to understand their extent of use of various sources.

\section{Informal sources}

Table 2 reveals that majority of respondents $(58.8 \%)$ were seeking less information from informal sources with score between as 5.007.33. About thirty four per cent respondents fell under medium level of use and rest only 7.4 per cent were utilizing at high level.

\section{Formal sources}

Majority of respondents (67.9\%) were utilizing formal sources of information at medium level as per the scores achieved by them, followed by high (20\%) and low categories $(12.1 \%)$.

\section{Mass media sources}

Majority of respondents (82.9\%) fell under medium category revealing that mass media sources were being utilizing by the respondents for receiving, sharing and utilizing the information related to buffalo husbandry practices. Results of the present study are in line with Mukesh et al., (2015) who reported more than sixty seven percent of the respondents in Jharkhand had medium to high level of exposure to mass media. Devaki et al., (2015) and Sabapara et al., (2016) also reported that majority of respondents in Thiruvallur district of Tamilnadu and southern Gujarat had medium level of utilization of mass media sources.

\section{Socio-economic profile of the buffalo owners}

This includes the gross family annual income and income generation through dairy. Gross family annual income referred as total income of the family earned through various sources viz., agriculture, animal husbandry, labour, business service etc. in a year. Income generation through dairy was operationalized as income earned from the milch buffalo rearing per annum through sale of milk, milk products, dung and buffaloes and was calculated by subtracting annual expenditure on dairying from annual gross income in dairying during data collection period i.e. 2017.

\section{Gross family annual income}

A perusal of the Table 3 reveals that majority of respondents $(67.1 \%)$ belonged to low gross annual income category i.e. Rs. $\leq 400000$ followed by 27.1 per cent respondents belonged to medium category (Rs. 400001 810164). Nearly 6 per cent respondents fell under high annual gross income category. Earlier studies as conducted by Prakash et al., (2014) and Adesh et al., (2014) reported average annual income of the majority of the farmers are Rs. 30097 - Rs. 232220 and Rs. $80,000-1$, 30,000 in Karnataka, Maharashtra and Uttar Pradesh respectively. Wherein in our study the average annual income was about three and half lakh. 
Table.1 Distribution of respondents according to their socio-personal characteristics ( $\mathrm{N}=240$ )

\begin{tabular}{|c|c|c|}
\hline Characteristics & Frequency & Per cent \\
\hline \multicolumn{3}{|l|}{ Age (Years) } \\
\hline Young (18-37) & 79 & 32.9 \\
\hline Middle (37-57 & 111 & 46.3 \\
\hline Old (57-76) & 50 & 20.8 \\
\hline Mean \pm S.D. & \multicolumn{2}{|c|}{$44.66 \pm 13.39$} \\
\hline \multicolumn{3}{|l|}{ Caste } \\
\hline Schedule Caste & 31 & 12.9 \\
\hline Other Backward Caste & 27 & 11.3 \\
\hline General & 182 & 75.8 \\
\hline \multicolumn{3}{|l|}{ Type of house } \\
\hline Hut & - & - \\
\hline kuccha & 3 & 1.2 \\
\hline Mixed & 17 & 7.1 \\
\hline Pucca & 220 & 91.7 \\
\hline \multicolumn{3}{|c|}{ Family structure (family type and family size) } \\
\hline \multicolumn{3}{|c|}{ Family type } \\
\hline Nuclear & 177 & 73.7 \\
\hline Joint & 63 & 26.3 \\
\hline \multicolumn{3}{|l|}{ Family size } \\
\hline Small $(\leq 7)$ & 176 & 73.3 \\
\hline Medium (8 - 11) & 53 & 22.1 \\
\hline Large $(\geq 12)$ & 11 & 4.6 \\
\hline Mean \pm S.D. & \multicolumn{2}{|l|}{$6.2 \pm 2.7$} \\
\hline \multicolumn{3}{|l|}{ Family education status (Score) } \\
\hline Low $(0-2.67)$ & 10 & 4.2 \\
\hline Medium (2.67-5.34) & 148 & 61.6 \\
\hline High (5.34-8) & 82 & 34.2 \\
\hline Mean \pm S.D. & \multicolumn{2}{|l|}{$4.83 \pm 1.29$} \\
\hline \multicolumn{3}{|l|}{ Family land holding (ha) } \\
\hline Landless & 35 & 14.6 \\
\hline Marginal $(<1)$ & 65 & 27.1 \\
\hline Small (1-2) & 69 & 28.7 \\
\hline Large (>2) & 71 & 29.6 \\
\hline Mean \pm S.D. & \multicolumn{2}{|l|}{$1.88 \pm 2.36$} \\
\hline \multicolumn{3}{|l|}{ Family occupation } \\
\hline Agriculture & 144 & 60.0 \\
\hline Animal Husbandry & 39 & 16.2 \\
\hline Government service & 27 & 11.2 \\
\hline Labourer & 8 & 3.4 \\
\hline Private service & 8 & 3.4 \\
\hline Self-employed & 14 & 5.8 \\
\hline \multicolumn{3}{|l|}{ Herd size (Cattle Equivalent Score) } \\
\hline Small $(\leq 5.0)$ & 172 & 71.7 \\
\hline Medium (5.1-10.0) & 45 & 18.8 \\
\hline Large $(\geq 10.0)$ & 23 & 9.5 \\
\hline Mean \pm S.D. & \multicolumn{2}{|l|}{$4.9 \pm 4.7$} \\
\hline \multicolumn{3}{|l|}{ Herd composition } \\
\hline Buffalo only & 154 & 64.2 \\
\hline Buffalo+ Cattle & 83 & 34.5 \\
\hline Buffalo+ Small ruminant & 3 & 1.3 \\
\hline Buffalo+ Cattle + Small ruminant & & \\
\hline
\end{tabular}


Table.2 Distribution of respondents according to their information seeking behaviour $(\mathrm{N}=240)$

\begin{tabular}{|c|c|c|}
\hline Characteristics & Frequency & Per cent \\
\hline \multicolumn{3}{|l|}{ Informal sources (Scores) } \\
\hline Low (5.00- 7.33) & 141 & 58.8 \\
\hline Medium (7.34 - 9.67) & 81 & 33.8 \\
\hline High (9.67-12) & 18 & 7.4 \\
\hline \multicolumn{3}{|l|}{ Formal sources (Scores) } \\
\hline Low (12.00- 13.66) & 29 & 12.1 \\
\hline Medium (13.67 - 15.33) & 163 & 67.9 \\
\hline High (15.34-17.00) & 48 & 20 \\
\hline \multicolumn{3}{|c|}{ Mass media sources (Scores) } \\
\hline Low (6.00- 9.33) & 36 & 15 \\
\hline Medium (9.34 - 12.67) & 199 & 82.9 \\
\hline High (12.67-16.00) & 5 & 2.1 \\
\hline
\end{tabular}

Table.3 Distribution of respondents according to their socio-economic characteristics $(\mathrm{N}=240)$

\begin{tabular}{|c|c|c|}
\hline Characteristics & Frequency & Per cent \\
\hline \multicolumn{3}{|c|}{ Gross family annual income (in ₹ ) } \\
\hline Low $(\leq 400000)$ & 161 & 67.1 \\
\hline Medium (400001-810164) & 65 & 27.1 \\
\hline High $(\geq 810165)$ & 14 & 5.8 \\
\hline Mean \pm S.D. & \multicolumn{2}{|c|}{$359682 \pm 306530$} \\
\hline \multicolumn{3}{|c|}{ Income generation from dairying in a year (in ₹ ) } \\
\hline Low $(\leq 164339)$ & 185 & 77.1 \\
\hline Medium (164340 - 327170) & 42 & 17.5 \\
\hline High $(\geq 327171)$ & 13 & 5.4 \\
\hline Mean \pm S.D. & \multicolumn{2}{|c|}{$122544 \pm 96251$} \\
\hline
\end{tabular}


Table.4 Distribution of respondents according to their socio-psychological characteristics $(\mathrm{N}=240)$

\begin{tabular}{|c|c|c|}
\hline Characteristics & Frequency & Per cent \\
\hline \multicolumn{3}{|l|}{ Risk orientation (Scores) } \\
\hline Low $(8-13.33)$ & 53 & 22.1 \\
\hline Medium (13.33-18.66) & 69 & 28.7 \\
\hline High (18.66-24) & 118 & 49.2 \\
\hline \multicolumn{3}{|c|}{ Economic motivation (Scores) } \\
\hline Low (15-18) & 22 & 9.2 \\
\hline Medium (18-21) & 144 & 60.0 \\
\hline High (21-24) & 74 & 30.8 \\
\hline
\end{tabular}

Income generation in a year through milch buffaloes

A perusal of the Table 3 reveals that majority of respondents $(77.1 \%)$ belonged to low income category i.e. Rs. $\leq 164339$ followed by 17.5 per cent respondents belonged to medium category (Rs. 164340 - 327170). About 5 per cent respondents fell under high income category. Earlier studies as conducted by Yogendra singh (2013) reported that 63.13 per cent of the beneficiaries of integrated murrah development scheme belong to medium average annual income (Rs. 9347 55643) and Rekha et al., (2015) reported that 60 per cent respondents under low income category (Rs. 15000-31683) from dairy in Haryana state.

Socio-psychological profile of the buffalo owners

This includes the risk orientation and economic motivation of the respondents towards animal husbandry.

\section{Risk orientation}

Table 4 reveals that 49.2 per cent of respondents fell under high risk orientation category followed by medium (28.7\%) and low $(22.1 \%)$. It could be justified in the sense that more number of respondents came from small and large farmers categories and they might be ready to take high risk in adoption of scientific practices of dairy for high production.

\section{Economic motivation}

Majority of the respondents $(60 \%)$ were inclined for economic gains from buffalo farming followed by high (30.8\%) and low (9.2\%) level. Results of our study are in consonance with Sarita et al., (2016) who also find that majority of dairy farmers belonged to medium economic motivation category in Haryana. However Ravi (2009) and Mali et al., (2014) reported high economic motivation in majority of dairy farmers of Bareilly district of Uttar Pradesh and Belgaum district of Karnataka state respectively.

In view of the above findings, it may be concluded that buffalo farmers of this region were educated, risk oriented, economically motivated and had sufficient land for fodder production. Agriculture was the main occupation of the majority of the buffalo owners and income from buffalo rearing is contributing a significant share in the total income of the farmers in the studied area. 


\section{Acknowledgement}

The authors are thankful to Director, ICARIVRI, Izzatnagar and Director, ICAR-CIRB, Hisar for providing facilities for conduction of the research work.

\section{References}

Annual Report. 2016-17. Department of Animal Husbandry, Dairying \& Fisheries Ministry of Agriculture \& Farmers Welfare, Government of India. Retrieved from http://dahd.nic.in/sites/default/filess/An nual\%20Report\%202016-17.pdf

Balaraju, B. L. 2016. Role of Indigenous cattle in the livelihood security of resource poor farmers: An exploratory study in Karnataka. Ph. D. Thesis, Indian Veterinary Research Institute, Uttar Pradesh, India.

Belakeri, P., K. Satyanarayan, V. Jagadeeswary, M. Kumar, S. Yathiraj, K. C. Veeranna and Rajeshwari Y. B. 2016. Socio-economic characteristics and information seeking behavior of livestock farmers of Karnataka, India. International Journal of Science Environment and Technology. 5(6): $4320-4327$.

Devaki, K., Senthilkumar, K. and Subramanian, R. 2015. Socio-Economic profile of livestock farm women of Thiruvallur district, Tamilnadu. International Journal of Science Environment and Technology. 4(5): 1322 - 1329.

India Economic Survey. 2015-16. Finance ministry, New Delhi, Manager of publication. $5 \mathrm{p}$.

Jadoun, Y. S. 2013. Integrated Murrah development scheme in Haryana: a critical appraisal. M.V.Sc. Thesis, National Dairy Research Institute, Karnal, Haryana, India.
Kumar, M., Gupta, J., Radhakrishnan, A. and Singh, M. 2015. Socio-economic Status and role of livestock to improve livelihood of tribes of Jharkhand. Research Journal of Agricultural Sciences. 6: 1421-1425.

Kumar, R. 2009. An Evaluation of Cattle Breeding interventions on Livelihood Security among dairy farmers: A Baif's Case. Ph.D. Thesis, Indian Veterinary Research Institute, Uttar Pradesh, India.

Mali, K. N., Belli, R. B. and Kitturmath, M. G. 2014. Study of the socio - economic characteristics of dairy and non- dairy farmers. Hind agricultural research and training institute. 9(1):54-58.

Nineteenth Livestock Census. 2012. Department of Animal Husbandry, Dairying and Fisheries. Ministry of Agriculture, Krishi Bhawan, Government of India. New Delhi. 16 p.

Rachna, Gautam, Malik, A., Sangwan, S. S., Khirbat, R. and Kamaldeep. 2017. Socio- economic profile of dairy farmers in Hisar district of Haryana. The Asian Journal of Animal Science. 12(1): 88-94.

Rathod, P. K., Nikam,T. R., Landge, S., Vajreshwari, S. and Hatey, A. 2011. Participation of rural women in dairy farming in Karnatka. Indian Research Journal of Extension Education. 11(2): 31-36.

Report of National dairy Development Board. $2017 . \quad$ Retrieved from http://www.nddb.org/information/stats/ milkprodindia on 22/07/2017

Sabapara, G. P., Fulsoundar, A. B. and Kharadi, V. B. 2016._Profile of dairy farmers and relationship with adoption of improved dairy husbandry practices in southern Gujarat India. Livestock Research International. 4(1):36-40.

Sarita, Singh, S. P., Malik, A., Sharma, M. and Ahuja, R. 2016. Socio-economic and psychological characteristics of 
dairy farmers of Hisar district. International Journal of Science, Environment and Technology. 5(5): $3466-3472$.

Verma, A. K., Lal, N., Avhad, S. R. and Hari R. 2014. Socio-economic status of farmers rearing Kherigarh, an indigenous breed of cattle. The Asian Journal of animal science. 9(2): 134 137.

World Bank. 2015. https://tradingeconomics.com/india/arab le-land-hectares-per-person-wbdata.html

Yadav, J. 2015. Effectiveness of livestock extension service delivery for women farmers under state department of animal husbandry in central plain zone of Uttar Pradesh. Ph.D. Thesis, Indian Veterinary Research Institute, Izatnagar, India.

Yadav, R., Sagar, M. P., Kumar, P.,Yadav, J., Singh, D. and Kumar, A. 2017. SocioEconomic Status of Dairy Based Women Self Help Group Members under SGSY in Rewari District of Haryana, India. International Journal of Current Microbiology and Applied Science. 6(11): 5385-5390.

\section{How to cite this article:}

Rekha Yadav, Hema Tripathi, Parveen Kumar and Nukala Ramesh. 2019. Socio- Personal, Economic and Psychological Status of Buffalo Owners in Murrah Breeding Tract of Haryana. Int.J.Curr.Microbiol.App.Sci. 8(08): 2446-2454. doi: https://doi.org/10.20546/ijcmas.2019.808.284 